\title{
EFISIENSI BIAYA PAKAN MELALUI PEMANFAATAN RAYAP POHON (Coptotermes Sp.) DALAM PEMBESARAN IKAN MAS KOMET (Carassius auratus auratus)
}

\author{
Efficiency of Food Cost by Utilizing Tree Termits (Coptotermes sp.) in Growing \\ Comet Goldfish (Carassius auratus auratus)
}

\author{
Ida Lapadi $^{1 *}$, Farida Wouw ${ }^{1}$, dan Nurhani Widiastuti ${ }^{1}$ \\ ${ }^{1}$ Jurusan Perikanan, FPIK UNIPA, Manokwari, 98314, Indonesia \\ *Korespondensi: idalapadi@yahoo.com
}

\begin{abstract}
ABSTRAK
Tujuan penelitian ini yaitu mengetahui pertumbuhan relatif ikan mas komet dengan persentasi pakan rayap dan pelet, rasio konversi pakan dan efisiensi pakan dari masingmasing perlakuan, dan menganalisis biaya pakan yang dikonsumsi. Perlakuan pada penelitian ini menggunakan pakan rayap dan pelet dengan persentase yang berbeda. Perlakuan $\mathrm{A}=$ rayap $20 \%$; pelet $80 \%, \mathrm{~B}=$ rayap $40 \%$; pelet $60 \%$ dan $\mathrm{C}=$ rayap $60 \%$; pelet $40 \%$. Hasil penelitian menunjukkan bahwa persentase pakan rayap dan pelet memberikan pertumbuhan relatif yang lebih baik pada perlakuan A 0,42 gram, B 0,10 gram dan C 0,26 gram. Nilai FCR yang terbaik diperoleh oleh perlakuan A 2,04 diikuti oleh C 3,3 dan B 7,9. Begitu pula dengan nilai Efisiensi pakan nilai terbaik diperoleh oleh perlakuan A 51,6\%, diikuti oleh C $29,58 \%$ dan B $11,02 \%$. Nilai biaya pakan yang terendah didapat oleh perlakuan A Rp. 4.112,-, diikuti oleh C Rp. 4.496,- dan B Rp. 5.008,-. Hasil penelitian menunjukkan bahwa pemanfaatan rayap pohon sebesar $20 \%$ dapat menjadi pakan komplementer dalam pembesaran ikan komet.
\end{abstract}

Kata kunci : Efisiensi pakan, rayap, ikan mas, komet, budidaya.

\begin{abstract}
The purpose of this research are to know comet goldfish growth by percentage termites and pelet feed, Food Convertion Ratio (FCR) and Food Efficiency (FE) of each treatment, and analyze the cost of feed consumed. The treatment on this study using termites feed and pelet by different percentages. Aquarium A treatment $=20 \%$ termites; $80 \%$ pelets, aquarium $\mathrm{B}=40 \%$ termites; pelets $60 \%$ and aquariums $\mathrm{C}=$ termites $60 \%$; pelet $40 \%$. The results showed that the percentage of pellet feed on termites and provide a better relative growth in treatment A 0.42 grams, C 0.26 grams and 0.10 grams B. FCR best value is obtained by treatment A 2.04 followed by C 3.3 and B 7.9. Similarly, the value of feed efficiency best values obtained by the treatment of A $51.6 \%$, followed by C $29.58 \%$ and B $11.02 \%$. Values lowest feed costs obtained by the treatment A Rp. 4112, -, followed by C Rp. 4496, - and B Rp. 5008, -. Results showed that utilization of $20 \%$ termite can be a complementary feed in comet fish rearing.
\end{abstract}

Key words : Food efficiency, termits, Gold fish, komet, aquaculture. 


\section{PENDAHULUAN}

Ikan mas komet (Carassius auratus auratus) selanjutnya disebut ikan komet, merupakan salah satu jenis ikan air tawar yang popular di kalangan masyarakat khususnya bagi pencinta ikan hias. Hal ini dikarenakan ikan komet memiliki warna yang indah serta bentuk dan gerakan yang menarik. Dikenal sangat jinak karena mudah hidup berdampingan dengan jenis ikan lain bila berada dalam satu tempat, karena sifatnya yang mudah menyesuaikan diri dengan lingkungan. Keunggulan utama ikan komet yaitu warna yang bernacam-macam seperti putih, kuning, merah atau perpaduan dari warna-warna tersebut. Hal inilah yang membuat ikan komet memiliki nilai jual yang tinggi, sehingga banyak orang yang berusaha untuk membudidayakannya untuk memperoleh keuntungan yang besar.

Keberhasilan dalam usaha budidaya antara lain tidak terlepas dari kualitas, kuantitas dan kontinuitas pakan yang diberikan. Pakan ikan merupakan salah satu faktor yang berperan penting dalam proses pertumbuhan ikan. Pertumbuhan ikan dapat berjalan optimal apa-bila jumlah pakan, kualitas pakan dan kandungan nutrisi terpenuhi dengan baik.

Ikan komet tergolong omnivora sehingga dapat memakan pakan alami, seperti krustasea kecil, serangga kecil, detritus, dan tumbuhan. Sedangkan di lingkungan budidaya dapat diberi pakan pelet (Lingga dan Susanto, 2003).

Pelet merupakan bentuk pakan buatan yang sengaja dibuat dan formulasinya disusun sesuai keinginan pembuatnya. Pelet terbuat dari beberapa macam bahan baku yang kemudian dibuat adonan dan dicetak menjadi bentuk batangan dengan ukuran $\geq 0,5 \mathrm{~cm}$ (Mudjiman, 2008; Zaenuri, $d k k$., 2014).

Penyediaan pakan buatan ini memerlukan biaya yang relatif tinggi, bahkan mencapai 60-70\% dari komponen biaya produksi (Emma, 2006). Umumnya pembudidaya ikan hias di Manokwari menggunakan pelet sebagai pakan bagi ikan hias, padahal harga pelet di kota ini tergolong mahal. Bahkan, biaya pakan dalam budidaya ikan hias di Manokwari mencapai 80\% dari komponen biaya produksi. Tingginya harga pakan disebabkan oleh mahalnya bahan baku yang digunakan, terutama tepung ikan dan panjangnya rantai distribusi. Oleh karena itu perlu dicari alternatif bahan pakan dengan harga relatif murah, mudah didapat dan mengandung nutrisi yang tinggi.

Salah satu organisme yang dapat digunakan sebagai pakan ikan yaitu rayap. Rayap memiliki kandungan protein yang cukup tinggi yaitu sebesar 20,4\% (Kuswardhani, 2015). Pemanfaatan rayap sebagai pakan ikan komet bertujuan untuk mengurangi penggunaan pakan pelet dalam pembesaran ikan komet.

Berdasarkan keunggulan utama ikan komet dan bervariasinya jenis pakan, maka perlu dilakukan penelitian menggunakan persentase antara pelet dan rayap dalam upaya mengurangi penggunaan pelet yang harganya relatif mahal.

Tujuan dari penelitian ini yaitu mengetahui pertumbuhan relatif ikan komet dengan perbandingan persentase pakan rayap dan pelet, mengetahui rasio konversi pakan dan efisiensi pakan dari masing-masing perlakuan dan menganalisis efisiensi biaya pakan yang dikonsumsi oleh ikan komet.

\section{METODE PENELITIAN}

\section{Waktu dan Tempat}

Penelitian berlangsung selama 1 bulan, yaitu November sampai dengan Desember 2014 yang bertempat di Sub Laboratorium Reproduksi Perikanan Unipa.

\section{Alat dan Bahan}

Alat yang digunakan terdiri dari akuarium, ember, serok, DO meter, $\mathrm{pH}$ meter, termometer, timbangan, dan kaliper. Adapun bahan yang digunakan yaitu benih ikan mas komet, air bersih, rayap dan pelet. 


\section{Perlakuan Sampel}

Ikan uji dimasukan dalam tiga akuarium terpisah. Pada setiap akuarium, diletakkan 8 ekor ikan. Masing-masing akuarium diberi pakan rayap dan pelet dengan persentase yang berbeda. Dosis pemberian pakan 3\% dari bobot tubuh ikan. Frekuensi pemberian pakan sebanyak 3 kali dengan cara ditebar di permukaan air. Adapun perlakuannya, yaitu: akuarium $\mathrm{A}=$ rayap $20 \%$; pelet $80 \%$, akuarium $\mathrm{B}=$ rayap $40 \%$; pelet $60 \%$, dan akuarium $\mathrm{C}=$ rayap $60 \%$; pelet
40\%. Rayap yang diberikan pada ikan terlebih dahulu disiram dengan air hangat hingga mati, kemudian dipotong-potong, tujuannya agar mudah dalam preparasi dan dimakan oleh ikan.

\section{Analisis Data}

Parameter yang dianalisis dalam penelitian ini yaitu laju pertumbuhan relatif, rasio konversi pakan (FCR), efisiensi pakan (EP), tingkat keberhasilan hidup (SR), dan biaya manfaat. Data yang diperoleh dalam penelitian ini disajikan dalam bentuk tabel dan gambar.

a. Laju Pertumbuhan Relatif

Laju pertumbuhan relatif dihitung menggunakan rumus dari Zonneveld, $d k k .$, (2001)

Keterangan:

$$
\mathrm{LPR}=\frac{W t-W 0}{W 0} \times 100 \%
$$

$$
\begin{array}{ll}
\mathrm{LPR} & =\text { laju pertumbuhan relatif } \\
\mathrm{Wt} & =\text { bobot ikan pada akhir penelitian }(\mathrm{g}) \\
\mathrm{Wo} & =\text { bobot ikan pada awal penelitian }(\mathrm{g})
\end{array}
$$

b. Rasio konversi pakan (FCR)

Rasio konversi pakan menggunakan rumus dari Zonneveld, $d k k$., (2001) :

Keterangan:

$$
\mathrm{FCR}=\frac{F}{(W t+D)-W 0}
$$

$$
\begin{array}{ll}
\mathrm{FCR} & =\text { food convertion ratio } \\
\mathrm{F} & =\text { berat total pakan yang diberikan }(\mathrm{g}) \\
\mathrm{Wt} & =\text { biomassa ikan pada akhir penelitian }(\mathrm{g}) \\
\mathrm{Wo} & =\text { biomassa ikan pada awal penelitian }(\mathrm{g}) \\
\mathrm{D} & =\text { bobot ikan mati }(\mathrm{g})
\end{array}
$$

c. Efisiensi Pakan (FE)

Rumus yang digunakan untuk menghitung efisiensi pakan menurut Zonneveld, $d k k$, (2001) yaitu :

$$
\mathrm{FE}=\frac{(W t+D)-W 0}{F} \times 100
$$

Keterangan:

$$
\begin{array}{ll}
\mathrm{FE} & =\text { food eficiency } \\
\mathrm{F} & =\text { berat total pakan yang diberikan }(\mathrm{g}) \\
\mathrm{Wt} & =\text { biomassa ikan pada akhir penelitian }(\mathrm{g}) \\
\mathrm{Wo} & =\text { biomassa ikan pada awal penelitian }(\mathrm{g}) \\
\mathrm{D} & =\text { bobot ikan mati }(\mathrm{g})
\end{array}
$$

\section{HASIL DAN PEMBAHASAN}

\section{Laju Pertumbuhan Relatif}

Pertumbuhan dirumuskan sebagai pertambahan ukuran panjang atau berat dalam suatu waktu, sedangkan pertumbuhan bagi populasi sebagai per- tambahan jumlah (Effendie, 1997). Pertumbuhan terjadi apabila jumlah pakan yang dicerna melebihi jumlah pakan yang diperlukan untuk mempertahankan hidup dan beraktivitas (Zonneveld, et al., 1991). Berdasarkan pengukuran pertumbuhan relatif ikan komet 
dengan perlakuan persentase rayap dan pelet diperoleh hasil perlakuan $\mathrm{A}=0,42$ $\mathrm{g}, \mathrm{B}=0,10 \mathrm{~g}$, dan C 0,26 g. Hasil terbaik diperoleh perlakuan A, diikuti C dan B. Hal ini menunjukkan bahwa pelet dengan persentase terbanyak memberikan pertumbuhan yang lebih baik (perlakuan A) jika dibandingkan dengan perlakuan $\mathrm{C}$ dan B. Pelet yang diberikan bermerek Takari dengan kandungan protein sebesar $30 \%$, lemak $3 \%$, serat $4 \%$, abu $12 \%$,vitamin A, D3, E, B1, B6, B12, nicin, biotin, panthotenic, colin, dan lainnya (PT. Central Proteinaprima Tbk.). Sedangkan rayap memiliki kandungan protein sebesar 20,4\% (Kuswardhani, 2015).

Pemanfaatan rayap sebagai pakan sebanyak $65 \%$ dalam pakan ikan nila memberikan pertumbuhan sebesar 11,36 gram sedangkan rayap sebanyak $35 \%$ memberikan pertumbuhan sebesar 5,82 gram (Awori, 2013). Rumalutur (2014), ikan hias pelangi arfak yang diberikan $100 \%$ pakan rayap belum memberikan hasil yang maksimal dalam pertumbuhan. Hal ini disebabkan karena ikan pelangi arfak masih dalam tahap domestikasi dalam lingkungan yang terkontrol.

\section{Rasio Konversi Pakan (FCR)}

Dari sejumlah pakan yang dimakan oleh ikan komet, kurang lebih hanya $10 \%$ saja yang digunakan untuk pertumbuhan, sedangkan selebihnya digunakan untuk tenaga, atau tidak dapat dicerna (Mudjiman, 2008). Rasio konversi pakan disebut juga dengan nilai ubah pakan, yang artinya apabila untuk menambah berat daging ikan dibutuhkan sebanyak $5 \mathrm{~kg}$ pakan, maka rasio konversi pakannya adalah 5 (Mudjiman, 2008). Nilai konversi pakan yang diperoleh untuk perlakuan A yaitu 2,04, perlakuan B yaitu, 7,9 dan perlakuan C 3,3. Artinya untuk menaikkan 1 gr daging ikan nila dibutuhkan pakan 2,04 g (perlakuan A), 7,9 g (perlakuan B) dan 3,3 (perlakuan C). Semakin rendah nilai FCR menunjukkan semakin efisien pakan dan pakan yang dikonsumsi digunakan dengan baik oleh ikan untuk pertumbuhan. Hal ini berarti, penggunaan pakan rayap dapat mengurangi penggunaan pakan pelet dalam pembesaran ikan komet. Awori (2013) memperoleh FCR sebesar 7,8 (rayap 65\%) dan 10,2 (rayap 35\%).

\section{Efisiensi Pakan}

Efisiensi pakan bertujuan untuk mengetahui apakah pakan yang diujicobakan efisien atau tidak, dalam arti apakah pakan yang diberikan diman-faatkan dengan baik dan memberikan partumbuhan bagi ikan komet. Hasil yang diperoleh melalui penelitian selama 30 hari, didapatkan pengaruh pemberian pakan dengan persentase yang berbeda terhadap efisiensi pakan. Nilai efisiensi pakan untuk perlakuan A yaitu 51,6\%, perlakuan B 11,02 \%, dan perlakuan C $29,58 \%$. Hal ini berarti perlakuan A lebih dimanfaatkan dan memberikan pertumbuhan dibandingkan perlakuan C dan B. Awori (2013) memperoleh efisiensi pakan sebesar $12,79 \%$ (rayap $65 \%$ ) dan 9,77 (rayap 35\%).

Kordi (2011), semakin tinggi nilai efisiensi pakan menunjukkan penggunaan pakan oleh ikan semakin efisien. Pakan dikatakan baik apabila nilai efisiensi pakan lebih dari 50\% atau bahkan mendekati $100 \%$ (Craigh dan Hefrich, 2002).

\section{Biaya Manfaat}

Pemanfaatan rayap sebagai pakan ikan komet bertujuan untuk mengurangi penggunaan pakan pelet dalam pembesaran ikan komet. Berdasarkan perhitungan (asumsi harga pakan Rp.8.000/ 100g), maka biaya pakan pellet selama pemeliharaan, diperoleh perla-kuan A memberikan biaya terendah yaitu sebesar Rp. 4.112,-, diikuti oleh per-lakuan C sebesar Rp. 4.496,-, dan terakhir perlakuan B sebesar Rp. 5.008,-. Artinya, untuk menghasilkan 100 gram ikan komet dibutuhkan biaya pakan sebesar Rp. 4.112,- (perlakuan A). Ber-dasarkan hasil tersebut berarti perlakuan A, memiliki biaya yang rendah, namun memberikan pertumbuhan lebih tinggi dan efisien 
dalam memanfaatkan pakan yang diberikan dibandingkan perlakuan B dan C. Hal ini berbeda dengan yang diperoleh oleh Awori (2013), peman-faatan rayap sebesar $65 \%$ dalam pakan ikan nila membutuhkan biaya lebih tinggi yaitu Rp. 1.522,- jika dibandingkan pakan rayap 35\% yaitu Rp. 1.323,- (asumsi harga pakan Rp.15.000/kg). Biaya yang dikeluarkan tidak berbeda jauh, tetapi menghasilkan pertumbuhan lebih tinggi dan efisien dalam meman-faatkan pakan yang diberikan.

\section{KESIMPULAN}

Pemanfaatan rayap pohon sebesar 20\% dapat menjadi pakan komplementer dalam pembesaran ikan komet.

\section{DAFTAR PUSTAKA}

Awori,W. 2014. Teknik Pembesaran Ikan Nila (Oreochromis niloticus) Dengan Pemberian Pelet dan Rayap Pohon (Coptotermes sp.) di Sub Laboratorium Basah Perikanan Unipa. Laporan PKL. Unipa, Manokwari.

Craig, S and L.A. Helfrich. 2002. Understanding Fish Nutrition, Feeds and Feeding. Virginia State University, Virginia.

Effendie, M.I. 1997. Biologi Perikanan. Yayasan Pustaka Nusatama, Yogyakarta. 163 hal.

Emma, Z.N. 2006. Studi Pembuatan Pakan Ikan dari Campuran Ampas
Tahu, Ampas Ikan, Darah Sapi Potong, dan Daun Keladi yang disesuaikan dengan Standar Mutu Pakan Ikan. Jurnal Sains Kimia Vol 10. No 1: 40-45.

Kordi, K.M.G.H. 2011. Panduan Lengkap Bisnis dan Budidaya Ikan Gabus. Lily Publisher, Yogyakarta.

Kuswardhani, D.S. 2015. Serangga sebagai Alternatif Pangan Sumber Protein Hewani. Perhimpunan Entomologi Indonesia. [www.peipusat.org. diakses tanggal 14 Februari 2016].

Lingga P. dan H. Susanto. 2003. Klasifikasi Ikan Komet (Carassius auratus). Agromedia Pustaka, Jakarta.

Mujiman, A. 2008. Makanan Ikan (edisi revisi). Penebar Swadaya, Jakarta. 192 hal.

Rumalutur, S. 2014. Domestikasi Ikan Pelangi Arfak (Melanotaenia arfakensis) di Laboratorium Perikanan Universitas Negeri Papua. Laporan PKL. Unipa, Manokwari.

Zaenuri, R., B. Suharto, dan A.T. Sutan Haji. 2014. Kualitas Pakan Ikan Berbentuk Pelet dari Limbah Pertanian. Jurnal Sumberdaya Alam dan Lingkungan, Vol 1 No 1: 31-36.

Zonneveld, N., E. A. Huisman dan H.J. Boon. 1991. Prinsip-prinsip Budidaya Ikan. Gramedia Pustaka Utama, Jakarta. 
